\title{
Fixed-Term Employment Contracts in Tertiary Education in New Zealand
}

\author{
Alan E. Woodfield
}

A

CCORDING to James Allan (1997:473), judicial activism is 'a fact of life in New Zealand today' and would have undesirable long-term consequences in terms of a more uncertain legal system and a weakened democracy. An important example of alleged judicial activism concerns fixed-term cmployment contracts, which are common in New Zealand's institutions of tertiary education. It is currently proposed to introduce them also for primary-school principals.

Critics of decisions of either the Employment Tribunal (ET) or the Employment Court (EC) argue that the courts have failed in their duty to enforce explicit contractual terms, effectively rewriting these after the event largely with a view to protecting property rights of individual workers. They also argue that the incentive effects of these decisions make all parties to future contracts potentially worse off. They typically recommend that the judiciary confine itself to enforcing explicit contractual terms, since this would be consistent with the major object of the Employment Contracts Act 1991 (ECA), namely, 'to promote an efficient labour market'.

During a recent visit to New Zealand, Richard Epstein, Professor of Law at the University of Chicago, chided the courts for continuing to 'chip away' at the basic structure of the ECA in an attempt to return to the days of protectionism, and recommended that "judges should resist the temptation to play Robin Hood after the fact' (The Press, 23 May 1996). John Hughes responded by arguing that judges were 'administering well-established principles under a legislative regime providing for personal grievances' (The Press, 3 June 1996). Noting that the ECA required a standard grievance procedure for all employment contracts in New Zealand, ${ }^{2}$ he argued that judges were 'simply applying an existing term of contract' when hearing an employee's argument regarding dismissal involving alleged unfairness. Further, judges were seen to be constrained to act within their statutory jurisdiction, which derived from the concept of 'unjustifiable dismissal'. The ECA was seen as carrying over the relevant legal principles embodied in case law prior to its enactment; thus, 'Parliament was aware of the settled law under those provisions and chose to endorse it'.

\footnotetext{
${ }^{1}$ Supporters of this general view include Baird (1996), Epstein (1996), Howard (1995), New Zealand Business Roundtable/New Zealand Employers Federation (1992), and Robertson (1996).

${ }^{2}$ Cf. ECA, s.26(a). Notably, s.147 prevents partics from contracting out of the provisions of the ECA.
}

Alan Woodfield is Senior Lecturer in Economics at The University of Canterbury. 
Hughes also argued that it might be wrongly inferred that an award of compensation can be made merely for the non-renewal of a fixed-term contract, whereas the Court of Appeal (CA) had established that such behaviour was unjustifiable only when the employer had broken some express or implied promise concerning renewal, or if the decision not to renew resulted from some wrong motive or unfairness on the employer's part. Finally, Hughes argued that well-established case law required contracts to be genuine and not to be used as a means by which legal obligations in a continuing employment relationship could be avoided.

\section{Personal Grievances and Fixed-Term Contracts}

Personal grievances are dealt with in Part III of the ECA. A common source of litigation is a claim under s.27(1)(a) that an employee has been 'unjustifiably dismissed', and/or, occasionally, under s.27(1)(b) 'unjustifiably disadvantaged'. These concepts are not independently defined in the ECA.

The role of these claims is of major importance in respect of fixed-term employment contracts. On the face of it, one could assume that when the contractual term expires, that that would be the end of the matter unless there were specific terms regarding future recontracting. This is not so. The courts may choose to imply terms in such contracts. Howard (1995:5-7) draws a distinction between those terms which are implied by statute or common law and those which are necessary to give business efficacy to contracts, arguing that the former are simply part of the legal definition of a contract taken in a particular context. For example, a fixed-term contract could imply a duty of fairness, confidence and trust as between an employer and employee. Business efficacy requirements are a different matter. No rule of law is involved; rather, an additional term relevant to a particular contract is implied in order that the intentions of the parties can be carried out.

In contract law, there is a general requirement of contracting in good faith. If this condition is satisfied, it is important that the intentions of the parties are realised. Where parties are in disagreement, courts will (and should) examine the express terms, and, in general, enforce them since they expressly state the intentions of the parties. Without such enforcement, there is scope for opportunistic behaviour on the part of one or other party, and the victims of such behaviour lose their expected share of the cooperative surplus that arises under voluntary exchange. When the contract is silent on certain matters, courts may attempt to introduce 'outside evidence', but only to give effect to the intentions of the parties, and certainly not to contradict these intentions, espccially not express contractual terms.

\section{The Actors Equity, ICI and Smith Cases}

Decisions reached in two important cases involving fixed-terms contracts preceded the passing of the ECA. These were Actors Variety etc $v$ Auckland Theatre Trust Inc ${ }^{3}$ (Actors Equity) and $N Z$ (except Northern etc) Food Processing IUOW $v$

3 [1989] 1 NZILR 463. 
$I C I^{4}(I C)$. The importance of these decisions, however, lies in relation to the first case dealing with fixed-term contracts heard after the passing of the ECA, namely,

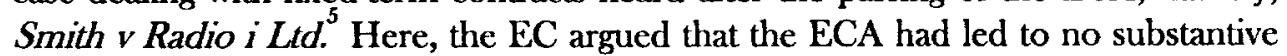
changes in the established law relating to fixed-term contracts.

In restating the law, the EC noted that fixed-term contracts would not automatically expire at their stated expiry date against the will of the employee if any of a set of certain circumstances existed. In essence, these included the following guidelines:

- the contract did not genuinely relate to an employer's operational requirements;

- the employer was unable to establish that there was a genuine reason for the fixed-term nature of the contract;

- where a genuine need for a fixed-term contract existed at the time of signing, the employer had failed to consider whether such a need still existed near the time of termination;

- there had been an express or implied promise of renewal which had not been kept, or else termination was in defiance of the employee's legitimate expectation of renewal; and

- termination had resulted from any wrong motive or unfairness on the employer's part.

Nevertheless, in Actors Equity, Cooke P dissenting held that the term 'dismissal' included the interpretation of 'sending away', and so in this sense nonrenewal of a fixed-term contract could constitute a 'dismissal'. Further, in ICI, where the EC gave consideration to whether the non-renewal of a fixed-term contract which provided for renewal by mutual agreement constituted a dismissal, although the Court felt bound by the CA's decision in Actors Equity it also stated a preference for the position taken by the dissenting judge in Actors Equity, and a similar position was taken by the Court in Smith. However, although clearly tempted, the Court did not adopt this interpretation of dismissal in its judgments at this stage, and cannot be accused of meddling on this account.

In Smith, a radio announcer claimed that she had been unjustifiably dismissed on the basis that she expected that her existing one-year contract would be renewed on request. The $\mathrm{EC}$, however, held that $\mathrm{Ms}$ Smith had refused a longer-term contract and had sought a shorter-term contract, knowing that both parties would need to agree on the terms and conditions of any subsequent contract. Radio i was not

\footnotetext{
${ }^{4}$ [1989] 3 NZILR 24.

${ }^{5}$ [1995] 1 ERNZ 281.
} 
seen as trying to avoid personal grievance provisions of the ECA, nor was the contract terminated by any wrong motive or unfairness. Ms Smith's claim failed.

Some critics of judicial meddling, however, consider that the EC should not have addressed many of these matters at all. The Court in Smith stated expressly that parliament had chosen not to modify the state of the law relating to fixed-term contracts when it had the opportunity to do so, and:

it is not for this Court to legislate in default and depart from established and conventional wisdom although that might in other respects arguably be consistent with the general tenor of the current legislation. (p. 309)

Howard's response (1995:2) was that the decision in Actors Equity was reached under a very different set of statutory employment law provisions than was Smith, 'a regime indeed in essential respects antithetical to it'. In this respect, Howard was strongly critical, claiming that 'the court is legislating when it relies on earlier decisions which have been overtaken by events in order to obstruct or defeat the clearly expressed will of parliament'.

Finally, an important message was delivered by the Court in Smith, namely, that the circumstances involved in the case were unlikely to be frequently repeated, since:

If the job function is to continue, then generally speaking there can be no justification for insisting on the contract coming to an end. (p. 310).

More usually the fixed term will have been stipulated for by the employer and insisted upon although the job function was to continue. (p. 311 ).

\section{When Does a Job Function Continue?}

The Haddon case. Two cases subsequent to Smith threw some light on the issue of when a job function continues. The first is Haddon $v$ Victoria University of Wellington involving an appeal against a decision of the ET. In this case, a fixed-term lectureship was made available to the appellant in order to provide cover for a temporarily vacant Chair in Zoology. The appellant argued that he would be offered a permanent position if his work was of a required standard, and if the fixed-term position became permanent. In the event, the Chair of Zoology did not return and a lectureship was established to fill the vacancy. The appellant was an unsuccessful applicant, and the ET decided there was no case of unjustifiable dismissal; the fixedterm contract had merely expired. On appeal, the appellant claimed unjustifiable dismissal as a result of reliance on the fixed-term nature of the position, and also alleged he was not fairly considered for the position. The employer was said to be bound by an implied contractual term of fair and reasonable dealing, and also 
bound to be a 'good employer' under s.77A of the State Sector Act 1988. The appellant claimed that, at the time of his appointment, he was given information leading to his holding a legitimate expectation of fair treatment when his contract expired, and his contract was ultimately brought to an end by either a wrong motive or unfairness by the respondent.

The university was judged to have properly considered the need for a fixedterm contract as still existing at the termination date, not to have promised to renew the contract, and not to have terminated the contract in defiance of a legitimate expectation of renewal. Nor was any wrong motive held. The EC held that there was no unjustified dismissal, consistent with the decision in Association of University Staff in Tertiary Education v Christchurch College of Education, a situation where a new position had been created. Further, in Christchurch Carpet Yarns v Maddock, the CA also concluded in a similar manner, but in this case the employment position continued in a permanent rather than a fixed-term position.

Notwithstanding the above, the EC in Haddon held that the appellant had a legitimate expectation of fair treatment in the appointment process to the new position, and that the university was bound to select impartially among suitably qualified persons. The ET's decision that the appellant had not been unjustifiably disadvantaged was set aside, and the EC subsequently held in Dr Haddon's favour.

If, following Smith, it was unclear what the status of fixed-term contracts would be when a job function continued, the subscquent decisions described above threw some light on the matter. It appeared that fixed-term contracts could expire if the job function continued if there had been some substantive change associated with the position involving either or both a change in the tenure of the contract or a change in the nature of the duties to be performed.

The Hagg Case. As for other circumstances, a watershed case soon emerged in Hagg $v$ The Principal, Auckland College of Education, which involved an appeal against a decision of the ET. The applicant had been appointed to a lectureship at the college for a two-year period under the Teachers Colleges Lecturers Award, had been reappointed to the (unadvertised) position for the remainder of the year, and had subsequently applied for and been appointed to another two-year lectureship. During its term, the employee received written advice that while an application for a future advertised position would be welcome, positions were likely to be fewer in number than previously, and that future employment could not be guaranteed. In the event, a personal grievance was lodged on the basis that the employee had developed a reasonable expectation of continuing employment and that he had been unjustifiably disadvantaged in not being appointed to a permanent position.

The ET disagreed with this assessment. On appeal, however, the EC held that the employer had established a basis for the employee to hold reasonable expecta-

\footnotetext{
[1991] 3 ERNZ 796.

8 [1994] I FRNZ 999.

9 [1995] 2 ERNZ 239.
} 
tions of continuing employment. The reasons included the fact that the employee's work was continuing, that he was being rehired to perform continuing tasks, and that he had been successful in being appointed to a second fixed-term position when the position had been advertised. In addition, Finnigan $J$ argued ${ }^{10}$ that ${ }^{\text {it }}$ was not normal for an employer to claim the privilege of subjecting its employees every couple of years to scrutiny and reassessment on the ground that some other person may be more suitable for the job at the time of reassessment'.

The EC was unimpressed by the policy of employing staff on fixed-term contracts in order to maintain flexibility. The exigencies of government funding changes and fluctuations in demand for specific courses were not seen as sufficient reasons to justify repeated rehiring on a fixed-term basis when the job function continued. The EC granted the appeal and reversed the Tribunal's findings, and ordered the employer to recognise the appellant's reasonable expectation of continuing employment by continuing his appointment as from the date of the Tribunal's decision.

The Purchas case. Following on the heels of Hagg came Purchas v The ViceChancellor, University of Canterbury. "The applicant claimed unjustified dismissal from his position as a temporary lecturer in the Department of Accountancy, Finance and Information Systems (AFIS) at the University of Canterbury, and also that he was unjustifiably disadvantaged by the failure of the respondent to confirm the applicant's employment in a continuing position.

In Purchas, the applicant had been an experienced management and chartered accountant, who first accepted a one-year temporary lectureship on 22 February 1989. The applicant's qualifications were inadequate for appointment to a permanent position, since only a BCom degree was held, and the (then) Head of Department (HOD) considered an MCom to be a 'prerequisite' to permanent appointment. The HOD actively encouraged the applicant to meet this prerequisite. In late 1989, a further fixed-term contract, this time of two-years duration, was sought by the HOD and approved by the employer. Judge Palmer considered (p. 5) that this arrangement would facilitate the completion of the masters degree, 'which would impact to the applicant's pronounced advantage upon his further employment by the university'. Further, the judge recognised that the 'rolling-over' of the temporary position was a necessary expedient, but held that 'impliedly this approach would change in future when Mr Purchas had completed his masters degree and was then eligible for continuing appointment'. This was followed by a succession of fixed-term contracts. In his judgment, Palmer J argued that the applicant was 'constructively encouraged' by the HOD to develop a career at the university, to the point where the HOD's 'obvious expectation was that the applicant's anticipated temporary appointments would accommodate him undertaking and successfully

${ }^{10}[1995] 2$ ERNZ 239 at 245.

"Unreported, CEC 37/96. 
completing a masters degree preparatory to appointment then on a permanent basis'.

Consistent with this view, Palmer J referred to a 'constructively purposeful strategy' adopted by AFIS whereby serious staff shortages would be attenuated or removed by 'home growing' prospective lecturers. This policy was successful in that several persons were subsequently appointed to tenured positions. In the view of Judge Palmer, however, the applicant appeared as an unintended victim of this strategy, since in the passage of time, AFIS had apparently changed its position on the matter. The judge considered that it was reliance upon this strategy which led the applicant to believe that he would certainly obtain a continuing/tenured appointment in AFIS'. Further, the judge held that the HOD had 'neither exceeded his authority in promoting the applicant's 'cause' to permanent appointment in AFIS nor inappropriately gave assurances to $\mathrm{Mr}$ Purchas concerning his employment situation and - more particularly - his prospects of tenured/permanent employment'. In the light of relevant information and assurances communicated by the HOD, Palmer J concluded that the applicant had 'compelling justification to conclude ... that he would in due course derive tenured employment in AFIS'.

The applicant completed his MCom degree in 1993, and in November of that year AFIS recommended the applicant, along with five others (four of whom were 'home-grown'), for permanent appointments in November 1993. Two, including the applicant, were not appointed, although the other was subsequently appointed. Palmer J held that the applicant should have been appointed at this stage, since 'all the criteria governing the appointment of the applicant to a continuing lecturing position in the department were satisfied'. Further, noting some confusion regarding the number of positions actually available at this stage, the judge held that the applicant should have been appointed to one of them.

The HOD then attempted (unsuccessfully) to have the applicant's position converted to a tenured position the following year, and encouraged the applicant to apply for an advertiscd continuing position during 1994. In the event, the position was not advertised but the applicant and another candidate were recommended for permanent appointment in the belief that two positions were available. This belief was mistaken, and AFIS's ranking of the two candidates placed the applicant second. The issue of the possible unappointability of the applicant was then discussed. The applicant became concerned about his future prospects and sought alternative employment, albeit unsuccessfully.

Late in 1994, a new HOD took over in AFIS, and in the views of the judge, the new HOD 'was certainly not as proactively supportive of $\mathrm{Mr}$ Purchas as a prospective tenured appointment in AFIS as was her predecessor ...'. Her view was that the applicant had no greater future prospects of permanent employment 'on the merits' than any other applicant, in part because of a lack of published research and also because of his failure to obtain a tenured position at a neighbouring university, to which Palmer J objected in that it failed to account for the legitimate expectation created by her predecessor. Mr Purchas's future temporary employment appeared threatened, although in fact it did continue. He sought to have his position con- 
verted to being permanent, and obtained support from the Association of University Staff which argued that such conversion would be a practical solution. This was unsuccessful. Nevertheless, AFIS as a whole, but with some dissension from senior staff members, subsequently recommended the applicant for one of four advertised permanent positions, but the university's staffing committee, chaired by the ViceChancellor, did not support the recommendation, considering the applicant "unappointable' and not 'on merit' the fourth-best candidate for the tenured position. The absence of the 'preferred' qualitication of $\mathrm{PhD}$, the absence of recent published research, and concern that the majority recommendation of AFIS did not reflect academic grounds were noted.

Palmer J, however, and aside from the applicant's claim of legitimate expectation, had no difficulty finding the applicant to be 'the fourth best candidate' and 'eminently appointable' (p. 37) and concluded that the committee, while proceeding with 'complete integrity of purpose', had made an incorrect decision on merit. As a consequence, Palmer J concluded that following the completion of his masters degree in 1993, the applicant reasonably held a legitimate expectation of permanent employment, which had been reinforced by the support of the previous HOD. His expectations were subsequently defeated, in the judge's views 'most unfairly'. The judge further considered the implied promise of appointment with tenure became an implied term in the fixed-term contracts themselves, and that the employer had failed to meet contractual obligations due to the applicant. The advice that his employment would cease at the end of 1995 was considered an unjustifiable dismissal, and the respondent was ordered to reinstate the applicant to a tenured lectureship as a primary remedy, with compensation including $\mathrm{NZ} \$ 10,000$ for 'humiliation, loss of dignity and injury to his feelings' resulting from the unjustifiable dismissal.

\section{The Court of Appeal Strikes Back}

In Haddon, the EC commented on the matter of availability of personal grievance procedures in the particular circumstances as follows:

that where an appointments process takes place during a subsisting employment relationship, either the implied duty of faimess or the good employer provisions of the State Sector Act give rise to a duty to act fairly during the appointments process.

In Victoria University of Wellington v Haddon, ${ }^{13}$ however, the CA was unanimous in reinstating the ET's decision. Reviewing Wellington $A H B \vee$ Wellington Hotel etc IUOW, the CA held that the phrase 'employee's employment' in s.27(1)(b) of ECA referred to the employment activity, or the 'on-the-job situation', not the em-

12

[1995] 1 ERNZ 375 at p. 377.

[13396], 1 ERNZ 139.

${ }^{14}$ [1992] 3 NZLR 658. 
ployment contract itself. Thus, arguments that an employee's employment is disadvantaged if prospects of employment in a different position with the same employer are prejudiced in some way, say, by the expiry of an existing fixed-term contract, were rejected by the majority of the $\mathrm{CA}$.

Two CA decisions then involved Hagg. In the first, Principal of Auckland College of Education $v$ Hagg, the College appealed the EC's decision to require $\mathrm{Mr}$ Hagg's reinstatement on the basis that he had been unjustifiably disadvantaged under s.27(1)(b) of the ECA. The CA held that any claim to a permanent position was not a personal grievance arising from the respondent's employment activity. Richardson $\mathrm{P}$ noted that the respondent had first been appointed to a fixed-term contract on the basis that if the position continued, it would be readvertised, and that while incumbents were entitled to apply for permanent positions, they would not be accorded preference. Mr Hagg's appointment to a second two-year fixedterm contract was in response to an advertisement for a short-term position of up to two years duration. It was also argued that the strongest evidence in favour of $\mathrm{Mr}$ Hagg's case for having a legitimate expectation of continuing employment emerged from the Director of the college's Mathematics Centre, who argued that while he would do everything possible to ensure that employment would be continuing for fixed-term contract holders, it was also known to all concerned that he had no powers to guarantee continuing employment. Even so, he suspected that certain expectations would have been derived from his statements of loyalty to his temporary staff. But if there were fewer positions than incumbent workers available to fill them, how could any one of them hold a legitimate expectation that a position was theirs?

Appealing to Haddon and Wellington AHB $\vee$ Wellington Hospital, etc IUOW, ${ }^{15}$ however, the CA distinguished between the employment activity in terms of the on-the-job situation and the employment contract itself, holding that grievances arising under s.27(1)(b) of the ECA applied to the former rather than the latter, and that later sections of the ECA could not be relied upon to provide opportunities for appointment to a different position under a different contract once a fixed-term contract had expired. It was further noted that s.77G of the State Sector Act 1988 required advertising and assessment, and selection for appointment to any permanent position to be on the basis of the person best suited for the position. Thus, it would appear that the college would have been in breach of $\mathrm{s} .77 \mathrm{G}$ had it reappointed the respondent to a permanent position without advertising and appointing on the basis of merit. Notwithstanding these arguments, however, the CA believed that $\mathrm{Mr}$ Hagg had not been given proper opportunity to argue a case for unjustifiable dismissal under s.27(1)(a), and remitted the matter to the EC.

Mr Hagg's second visit to the $\mathrm{EC}^{16}$ proved to be as profitable as his first. Here, Finnigan $\mathrm{J}$ largely reasserted his previous position, holding that the college's policy of employing Mr Hagg on a series of fixed-term contracts

\footnotetext{
${ }^{15}$ [1992] 3 NZLR 658.

16

Hagg v Principal, Auckland College of Education [1996] 2 ERNZ 486.
} 
was designed to enable the College to terminate his employment when it could not afford his salary or might not have demand for the course he taught. The employment was to continue indefinitely as long as the need continued and there were sufficient funds. This is not different in character from a number of employment situations. However, the method of using fixed-term contracts was aimed at resolving any issues that might arise should the College wish to dispense with Mr Hagg's services. This does not accord with equity and good conscience. (p. 486)

Finnigan J distinguished $\mathrm{Hagg}$ from $H a d d o n$ in that in the former case, a fixed-term contract was due to expire where the position itself was ongoing. Noting that the college was legally bound to allow Mr Hagg's contract to expire and to advertise an available position, Finnigan $J$ posed the question of whether using the award provision for short-term appointments rather than for permanent appointments constituted an unfair action by the employer. The judge found these actions to be unfair, and unfair independently of the guidelines established in Smith, on the basis that Mr Hagg had been maintained in temporary employment past the point of no return, in which case it was fair to provide Mr Hagg with a permanent employment contract in order to restore service entitlement previously bargained away. As a consequence, Finnigan J held that the claim of unjustifiable dismissal was made out.

The college appealed this decision. ${ }^{17}$ Difficulties with aspects of Judge Finnigan's arguments were evident. He had acknowledged that the closely related claim of unjustifiable disadvantage may have been 'knife-edged', that $\mathrm{Mr}$ Hagg had knowingly entered into his series of fixed-term contracts, and had been aware of the award which permitted such contracts. Mr Hagg was also aware of the opportunity cost of taking up temporary employment if he resigned his permanent position as a deputy school principal, and had been warned by the college to make provision for leave. All parties were aware that permanent employment at the college could not be guaranteed to incumbent temporary staff who applied for permanent positions, which in turn were required by statute to be advertised and filled on the basis of merit. Thus, it must be asked, wherein lies the basis for legitimate expectation of permanent appointment on the part of the employee and unfairness to make such an appointment on behalf of the employer?

The CA answered in the following terms. First, the exercise of the equity and good conscience provisions under s.104(3) of the ECA could not be inconsistent with the ECA or any other Act or with any other applicable collective employment contract. In turn, this did not permit the EC to depart from a proper interpretation of s.27(1)(a) in considering unjustifiable dismissal, and it would be inconsistent with the ECA for the EC to give effect to the provisions of the applicable collective contract which required advertising and preference to the best person suited for the position.

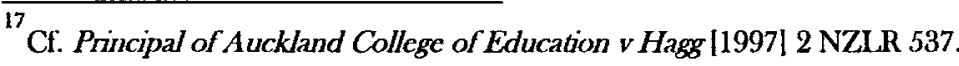


Second, equity and good conscience provisions could similarly not be invoked in order to not give effect to Part II of the ECA, which established that employment relationships were to be governed by negotiation between the relevant parties.

Third, the mere expiry of a fixed-term contract did not constitute a dismissal, and ss.77G and $77 \mathrm{H}$ of the State Sector Act precluded continuation of the employment after it had run its stated course. Thus, the college was held not to have unjustifiably dismissed $\mathrm{Mr}$ Hagg by allowing the second two-year contract to expire and by failing to make a permanent appointment without recourse to the process laid out in statute.

Fourth, no special rules of contract apply to employment contracts.

Fifth, the issue of the expiration of a given fixed-term contract would not call for special consideration of the will of the employee, and s. 57 of the ECA was available to deal with claims of harsh and oppressive contracts.

Finally, no special guidelines or rules (as stated in Smith, for example) should determine the issue of expiry of a fixed-term contract.

The CA, however, did address two circumstances under which fixed-term contracts might not automatically expire. The first concerns so-called 'sham' contracts, where the parties mutually conceal the reality of a continuing employment relationship. It is unlikely that contracts of this nature would be widespread. ${ }^{8}$ The second is where representations inconsistent with termination by expiry of the fixed term have been made by the employer and employees rely on these representations to their cost. Since neither of these circumstances applied in Hagg, the CA granted the appeal.

In all the circumstances, it might well be asked what the college was to do at the end of Mr Hagg's first contract. The award permitted temporary as well as permanent appointments, and required them to be advertised. Suppose the college had advertised a permanent position, and that $\mathrm{Mr}$ Hagg applied. If successful, his service entitlements would be re-established. What if he were not appointed? He had chosen not to apply for an advertised permanent position at the time of his first appointment in the belicf that he would not be successful. If he had not resigned from his permanent school position, he could have reverted to this employment. But a permanent position was not advertised. Instead, Mr Hagg accepted another temporary position. The facts are that $\mathrm{Mr}$ Hagg twice survived the advertising process for temporary positions. He was never subject to the advertising process for permanent positions. Nevertheless, the case for continuing employment seems to have been made on the basis of Mr Hagg's successes in obtaining temporary employment (which appeared to establish his merit as an employee) and on the fact that the nature of the work was similar for both short-term and permanent employees.

To complicate matters further, suppose that the position had becn advertised as either temporary or permanent, and that Mr Hagg had been appointed to the temporary position. Would the EC then wish to direct the college to instead 'convert'

${ }^{18}$ See the discussion in Hughes, Roth and Anderson (1997:3-17). 
the position to permanent employment in the circumstances? What if another person had been appointed to the fixed-term position, when it appeared that $\mathrm{Mr}$ Hagg was the most suitable applicant for this position, but did not receive it on the grounds that the EC would entrench it as permanent? It is not clear that Mr Hagg's interests were necessarily well served by the EC in either circumstance. Anticipating that the EC will direct an employer to make a permanent appointment to an incumbent temporary employee if the latter is successful in obtaining re-employment as a temporary employee creates an incentive for an employer to offer a fixed-term contract to a person who may not be best suited for the job, hoping that the appointment might not be appealed, or at worst be defensible on appeal. These circumstances do not appear to accord with labour market efficiency.

\section{Settled and Unsettled Questions}

The most recent $\mathrm{CA}$ decisions have placed employment contracts firmly back inside the general rubric of the law of contract, which emerged under common law as opposed to statutory law. Central to the modern law and economics movement is a general argument that irrespective of issues of fairness, justice, equity, or good conscience (however these might be independently defined, if at all), the concept of cconomic efficiency is typically consistent with the bulk of case law emerging from the common law, although the argument does not generally extend to that of statutory law.

As for the battle concerning judicial meddling in the field of personal grievances involving s.27(1) of the ECA, it appears that the supporters of the argument that meddling has occurred have prevailed. A fair amount of baggage associated with earlier legislation seems to have been carried over by the EC in particular, but the CA has largely decided that it should have remained as part of history. Such an outcome may be expected to fuel the calls for the removal of specialist courts dealing with employment matters, and will bring some joy to those who accept the fulminations of Howard (1995:14) that with respect to personal grievances, the EC 'has no intention of allowing any fixed-term contract to take effect according to its terms unless it accords with what can only be called the Court's own social agenda, however incompatible with the objects of the ECA'.

In retrospect, however, perhaps it should not be too surprising that the field has been plagued by dissension. It is at least arguable that the ECA as framed was insufficiently precise in some contentious areas, especially those involving the termination of employment relationships. It would perhaps have been helpful had parliament clarified the extent to which previously relevant case law was supposed to carry over (or not) with the passage of the Act. An intriguing question, however, especially in light of calls to abandon specialist courts, is whether the drafters of the ECA may have been deliberately imprecise on this matter, given that they knew, or should have known, that the ET/EC would likely treat personal grievances as 'business as usual' in the absence of inconsistency with the Act. For those who did not

${ }^{19}$ Robertson (1996) argues that the creation of specialist courts threatens judicial independence. 
prevail in this debate, however, and who supported the restatement of 'settled' principles of law relating to fixed-term contracts as restated in Smith and reiterated in Haddon, there is presumably some discomfort felt by in the summary of Hughes, Roth and Anderson (1997:3-14) who note that the reference to express or implied promise of renewal remains the only surviving applicable principle from the guidelines. 20

Naturally, discomfort with the CA's ruling in Hagg has led some to question the CA itself. Thus, Anderson (1997:42) notes that the CA 'appears to prefer a more neo-classical/new right approach to employment contracts, as advocated by writers such as Epstein', and that the CA's regarding of the employment relationship as 'strictly contractual' 'is not an assumption shared by all commentators'. Further, and to give perhaps a different dimension to the nature of 'meddling' by the judiciary, "the case appears to confirm the view that the Court of Appeal is less willing to take account of the specialised expertise and knowledge of the $\mathrm{EC}$ on employment issues, and now regards itself as more appropriately placed to develop both the overall trends in labour law as well as the details of the law'. Yet a clear inference in the CA's recent decisions is that the $\mathrm{EC}$ has failed in important matters of interpretation of the ECA. It would seem more appropriate for the EC's defenders to address these issues of substance than to argue huffily about turf rights. If labour market efficiency implies that labour market services should flow to where they are valued most highly, this objective is unlikely to be promoted by the protection of highly tenuous implicit contractual terms for incumbent fixed-term workers in the face of competition from more highly qualified potential employees. Moreover, in a recent landmark unanimous decision Aoraki $v$ MCGavin, ${ }^{22}$ the CA overturned its own earlier split decision in Brighouse Ltd $v$ Bilderbeck, ${ }^{23}$ holding that in the absence of a specific contractual provision an employer is not liable for making com-

\footnotetext{
${ }^{20}$

${ }^{20}$ While the CA decision in Hagg regarding unjustifiable dismissal was unanimous, a separate judgment was delivered by Thomas J, who argued that the matter was not as clear-cut as might be believed. In particular, it was emphasised that there may be shifts in the nature of employment relationships where there is an express or implied promise of renewal, or where there is a legitimate expectation on the part of the employee to that effect. The essence was seen to be whether or not a given fixed-term contract is genuine. Unfortunately, Thomas J did not elaborate on what might constitute a 'genuine' fixedterm contract. Hughes $(1997: 49)$ argues that this specific problem was dealt with previously by the Labour Court with respect to 'operational needs' guidelines, drawing on ILO Convention 158, Art 2(3). For those favouring a codification of the law on fixed-term contracts to include non-renewal of a fixed-term contract with 'genuine need' based on 'operational requirements' as the basis of justifying dismissal, and which would involve the codification of guideline 2(a) as stated in Smith, there is cold comfort in the majority judgment of the CA in Hagg. Here, no basis was found 'either in the principled application of the law governing the construction of contracts or in the provisions of the Employment Contracts Act for the guidelines formulated by the Full Court'.

${ }^{21}$ Interestingly, Bowden (1997:80), while finding it difficult to imagine what might replace the ET, also finds it 'hard to justify the existence of a special judicial body' like the EC.

22

23

Unreported, CA 2/9, 15 May, 1998.

[1994] 2 ERNZ 243 (CA).
} 
pensatory payments for redundancy in the event of a job lost through genuine redundancy. This decision is consistent with the apparent trend by the CA to return employment contracts to the fold of contracts in general.

Finally, it may be noted that Purchas is currently under appeal. There are many subtleties associated with what the EC appeared to decide was a straightforward case. The issues of the nature of the alleged implicit promise of permanent employment, whether accurate and complete information was conveyed to the respondent, whether the university was obliged to hire Mr Purchas at any time given the provisions of the State Sector Act, and whether the main remedy of reinstatement to a position that was never offered to $\mathrm{Mr}$ Purchas was any less a contradiction in law than in language, are well worthy of critical scrutiny. But perhaps the most important issue is whether agreement is found with Judge Palmer's view (p. 37) that it was 'a paradox of monumental proportions to determine that Mr Purchas lacked the credentials for tenured appointment in AFIS ...' given that the single clear distinguishing feature of a university is its contributions to research, and given that the university's staffing committee, along with senior members of staff in AFIS, considered this to be an important area of weakness in Mr Purchas's case for permanent appointment. If Judge Palmer's assessment of the decision of the university's staffing committee as being in error does not stand up in the face of critical scrutiny, it would seem to take judicial activism (as opposed to implicit contract performance) by the EC to a new (low) plane.

\section{References}

Allan, J. (1997), 'The Rise of Judicial Activism in New Zealand', Agenda 4: 465-74.

Anderson, G. (1997), 'Trends in Labour Law: The Court of Appeal and the Hagg Decision', Employment Law Bulletin 3: 42.

Baird, C. (1996), The Employment Contracts Act and Unjustifiable Dismissal: The Economics of an Unjust Employment Tax, New Zealand Business Roundtable/New Zealand Employers Federation, Wellington.

Bowden, R. (1997), 'The Employment Contracts Act: Common Law and Uncommon Economics', New Zealand Economic Papers 31: 65-83.

Epstein, R. (1996), Employment Law: Courts and Contracts, New Zealand Business Roundtable, Wellington.

Howard, C. (1995), Interpretation of the Employment Contracts Act 1991, New Zealand Business Roundtable/New Zealand Employers Federation, Wellington.

Hughes, J. (1997), 'Fixed Term Contracts in the Private sector After Hagg', Employment Law Bulletinn 3: $46-51$.

—, P. Roth \& G. Anderson (1997), Personal Grievances, Butterworths, Wellington.

New Zealand Business Roundtable/New Zealand Employers Federation (1992), A Study of the Labour/Employment Court, Wellington.

Robertson, B. (1996), The Status and Jurisdiction of the New Zealand Employment Court, New Zealand Business Roundtable, Wellington. 